\title{
PERANCANGAN LAMPU PEMIKAT CUMI-CUMI MENGGUNAKAN LIGHT EMITTING DIODE (LED)
}

\section{DESIGN OF THE SQUID LAMP AS ATTRACTOR USING LIGHT EMITTING DIODE (LED)}

\author{
Muhammad Johar Rudin ${ }^{1}$, Mochammad Riyanto ${ }^{2}$, Ari Purbayanto ${ }^{2}$ \\ ${ }^{1}$ Program Studi Teknologi Perikanan Laut, \\ ${ }^{2}$ Departemen Pemanfaatan Sumberdaya Perairan, \\ Fakultas Perikanan dan Ilmu Kelautan, IPB University \\ Korespondensi: mochammadri@apps.ipb.ac.id
}

\begin{abstract}
Squid jigging fisheries have increased very rapidly in Indonesia. The squid jigging fishing has a lamp as a fishing auxiliary with relatively large power. Squid jigging boat is usually using Metal Halide (MH) lamps of 6-20 units with an power of 24-30 kW. MH lamps consume a lot of energy which affects the high fuel loss. For this purpose, an alternative lamp that is more energy efficient is needed, namely the Light Emitting Diode (LED) lamp. The research was conducted by designing the squid LED lamp to be applied in squid jigging boats. The design of a squid LED lamp can be equal to the main properties and characteristics of the MH lamps. The conceptual design of the lamp circuit was carried out by gathering all the materials related to the light properties of the LED lamp and the attraction of the squid to the blue LED lamp. Then, determine the light distribution of MH and squid LED lamps, as well as selecting the appropriate material so that the LED lights can be stable. Based on the results, the temperature measurements and light illumination on each LED chip, were stable until the end of the observation. The light intensity distribution of the Squid LED lamps was only reduced by 10,57\%. The LED design can be applied to squid jigging boats as a substitute alternative to $\mathrm{MH}$ lamps.
\end{abstract}

Keyword: design, LED, metal halide, squid

\begin{abstract}
ABSTRAK
Perikanan tangkap cumi-cumi telah mengalami peningkatan sangat pesat di Indonesia. Kapal pancing cumi-cumi memiliki alat bantu penangkapan lampu dengan daya relatif besar. Biasanya kapal memakai lampu Metal Halide $(\mathrm{MH})$ yang berjumlah 16-20 unit (dengan daya 24-30 kW). Lampu MH membutuhkan energi yang cukup besar dan berpengaruh terhadap kebutuhan bahan bakar minyak yang tinggi. Untuk itu diperlukan altenatif lampu yang lebih hemat energi yaitu Light Emitting Diode (LED). Penelitian ini dilakukan dengan membuat rancangan lampu LED cumi-cumi yang aplikatif untuk diterapkan di kapal pancing cumi-cumi. Pendekatan yang dilakukan adalah dengan merancang bangun lampu LED cumi-cumi yang mampu mendekati sifat dan karakteristik utama lampu MH yang saat ini digunakan. Rancangan konseptual rangkaian lampu LED cumi-cumi dilakukan dengan mengumpulkan semua materi yang terkait dengan sifat cahaya lampu LED dan ketertarikan dari cumi-cumi pada lampu LED warna biru. Kemudian, dilakukan penentuan sebaran cahaya lampu MH dan LED cumi-cumi, serta pemilihan jenis bahan material yang sesuai agar lampu LED bisa stabil. Berdasarkan hasil penelitian berupa pengukuran suhu dan iluminasi cahaya pada tiap chips LED terlihat stabil hingga akhir pengamatan. Sebaran intensitas cahaya lampu LED cumi-cumi hanya berkurang 10,57\%. Hasil rancang bangun LED dapat diterapkan pada perikanan cumi-cumi sebagai alternatif pengganti lampu MH.
\end{abstract}

Kata kunci: cumi-cumi, LED, metal halide, rancangan 


\section{PENDAHULUAN}

Perikanan pancing cumi-cumi (squid jigging) mengalami perkembangan cukup pesat di Indonesia, disebabkan karena meningkatnya transformasi kapal penangkap ikan ke kapal penangkap cumicumi. Penambahan kapal pancing cumicumi mencapai $288 \%$ pada periode 2015 2018 (Christianto 2019). Penambahan yang pesat ini berpengaruh terhadap peningkatan penggunaan energi yang cukup besar pada kapal pancing cumi-cumi. Kapal pancing cumi-cumi menggunakan lampu Metal Halide (MH) yang memiliki daya energi sangat besar. Satu kapal pancing cumi-cumi menggunakan lampu MH sebanyak 16-20 unit dengan daya 24-30 kW. Penggunaan lampu $\mathrm{MH}$ oleh nelayan saat ini dianggap sebagai lampu yang efektif sebagai alat bantu untuk mengumpulkan cumi-cumi, namun demikian lampu ini masih memiliki beberapa kekurangan antara lain membutuhkan daya yang besar, umur teknis yang relatif pendek dan tidak ramah lingkungan (Kuo dan Shen 2018) serta beberapa logam metal yang dapat merusak dan mengganggu kesehatan manusia dan lingkungan (Hua dan Xing 2013). Penggunaan lampu $\mathrm{MH}$ yang besar menyebabkan pemborosan energi dan berpengaruh terhadap keamanan dan kesehatan nelayan dalam pengoperasian pancing cumi-cumi. Berdasarkan permasalahan tersebut diperlukan teknologi pencahayaan lampu alternatif yang hemat energi dan aman terhadap nelayan. Teknologi yang bisa diterapkan adalah Light Emitting Diode (LED).

Light Emitting Diode (LED) merupakan lampu yang dibuat dari bahan semikonduktor yang hanya dapat dialiri arus Direct Current (DC), hemat energi, daya tahan lama, tingkat voltase yang rendah dan memiliki respons pencahayaan yang cepat (Kuo dan Shen 2018; Matsushita et al. 2012). Penggunaan LED pada operasi penangkapan ikan mampu menurunkan tingkat konsumsi bahan bakar hingga 16-20,2\% (Kuo da Shen 2018; Yamashita et al. 2012). Lampu LED juga memiliki tingkat iluminasi cahaya yang tinggi dengan daya rendah dibandingkan dengan lampu lainnya (Rudin et al. 2017; Susanto et al. 2017). Namun demikian, penggunaan lampu LED dengan desain dan konstruksi khusus untuk digunakan pada perikanan pancing cumi-cumi belum dilakukan.

Teknologi LED yang dirancang perlu dilakukan agar dapat digunakan untuk perikanan pancing cumi-cumi. Perancangan LED yang dilakukan dengan memperhatikan sifat dari penyebaran cahayanya dibandingkan dengan lampu MH. LED mempunyai spektrum cahaya yang mengarah pada sudut divergensi yang kecil dibandingkan lampu $\mathrm{MH}$ yang memiliki arah pancarannya yang sangat luas (Hua dan Xing 2013). Rancang bangun LED diawali dengan membandingkan chip yang sesuai dengan pola sebaran cahaya, mencari luasan casing lampu dan menentukan formula dari iluminasi cahaya yang sesuai dengan bentuk kapal serta sebaran cahaya terdapat pada area sekitar kapal (Kuo dan Shen 2018; Shen et al. 2013). Penelitian ini dilakukan untuk membuat rancangan LED yang mampu mendekati sifat dan karakteristik utama lampu MH. Dalam pembuatannya harus memperhitungkan ukuran dan tata letak lampu LED agar sesuai dengan bentuk lampu MH. Tujuan dari penelitian ini ialah merancang lampu LED cumi-cumi yang sifat sebaran iluminasinya mendekati lampu MH. Hipotesis dari penelitian ini yaitu rancang bangun lampu LED yang akan dibuat mempunyai kesamaan sebaran dan intensitas cahaya dengan daya yang rendah sehingga akan menghemat penggunaan $\mathrm{BBM}$ dibandingkan dengan lampu MH.

\section{METODE PENELITIAN}

Penelitian ini terdiri dari dua tahap yaitu merancang dan membuat lampu LED cumi-cumi dengan daya 450 watt sebagai pemikat cumi-cumi. Pemilihan chip High Power LED (HPL) daya 50 watt berwarna biru yang digunakan dalam membuat lampu LED cumi-cumi merupakan hasil dari perbandingan antara satu lampu $\mathrm{MH}$ daya 1.500 watt dengan iluminasi cahaya sebesar 589 lux dan chip LED daya 100 watt dengan iluminasi cahaya sebesar 129 lux. Perhitungan iluminasi cahaya ini didapatkan dari data hasil pengukuran yang telah dilakukan Wibisono dan Baheramsyah (2016) dengan menggunakan luxmeter. Penentuan banyaknya kedua jenis lampu berdasarkan pada jumlah iluminasi cahaya yang digunakan oleh kapal cumi-cumi pada umumnya sehingga memiliki daya energi yang berbeda. Kapal penangkap cumicumi menggunakan lampu $\mathrm{MH}$ berjumlah 12 unit lampu dengan konversi iluminasi cahaya sebesar 7.068 lux. Pemasangan lampu biasanya menggunakan 6 lampu dari masing-masing jenis lampu antara lampu 
MH dan LED hasil rancang bangun, sesuai dengan penggunaan lampu LED hasil rancang bangun pada pengoperasian kapal purse seine (Sofijanto et al. 2018). Iluminasi cahaya dari 6 unit lampu MH sebesar 3.534 lux. Separuh dari total iluminasi cahaya $\mathrm{MH}$ akan diganti dengan menggunakan lampu LED cumi-cumi. Lampu LED dengan daya 100 watt memiliki iluminasi cahaya sebesar 129 lux, dimana jika total 6 unit lampu MH memiliki iluminasi cahaya sebesar 3.534 lux dibagi dengan 129 lux maka akan mendapatkan lampu LED sebanyak 27 unit lampu dengan daya 100 watt. Chip lampu yang digunakan dengan daya 50 watt sehingga total keseluruhan chip yang dipakai sebanyak 54 chip LED. Jadi untuk mendapatkan desain lampu dengan jumlah 6 lampu LED cumi-cumi dalam satu kontruksi dibutuhkan 9 chip LED. Berikut Tabel 1 perbandingan lampu pada penentuan chip LED yang digunakan dalam perancangan lampu LED cumi-cumi.

\section{Rancangan konseptual rangkaian lampu LED cumi-cumi}

Penggunaan lampu LED warna biru didasarkan pada penelitian tentang respon tingkah laku cumi-cumi terhadap lampu LED biru (Tirtana 2019) yang menunjukkan bahwa respons dari cumi-cumi yang tertarik cahaya warna biru dengan kondisi berada pada zona terang intensitas rendah antara $1 \times 10^{-4}-1 \times 10^{-7} \mathrm{~W} / \mathrm{cm}^{2}$. Penggunaan cahaya dengan warna biru (spektrum 450-500 nm) memiliki penetrasi yang sangat baik ke dalam air pada saat pengoperasian kapal pancing cumi-cumi (squid jigging) (Matsushita et al. 2012).

Warna lampu LED yang digunakan adalah biru yang sesuai dengan konsep rancangan desain dan hasil analisis dari pola sebaran cahaya lampu $\mathrm{MH}$, serta beberapa penelitian tentang tingkah laku cumi-cumi terhadap respons cahaya warna biru. Lampu MH diukur intensitas cahayanya untuk mendapatkan pola sebaran intensitas cahaya, yang digunakan sebagai acuan pembuatan rancang bangun lampu LED (Tabel 2).

Lampu MH yang digunakan memiliki daya sebesar 1500 watt. Lampu ini mempunyai bentuk silinder lonjong dengan panjang berkisar 200-250 mm. Intensitas cahaya $\mathrm{MH}$ diukur untuk dianalisis pola sebaran cahaya sebagai acuan untuk perakitan lampu LED cumi-cumi. Panjang penampang lampu LED yang dibuat sama dengan lampu $\mathrm{MH}$ yang sering digunakan oleh nelayan.

Pengukuran intensitas di medium udara dilakukan pada malam hari di ruangan gelap dengan ukuran $2 \mathrm{~m} \times 2 \mathrm{~m}$ dengan menggunakan ILT (International Light Technologies) 5000 research radiometer. Lampu MH dinyalakan dengan daya energi yang berasal dari genset (Kenika Gasoline Generator ZH3500 3,5 kW). Pengukuran intensitas cahaya lampu $\mathrm{MH}$ berjarak $1 \mathrm{~m}$ dari sensor ILT 5000 Research Radiometer dengan interval sudut setiap $10^{\circ}$ (Gambar 1 ). Setiap interval $10^{\circ}$ dari setiap pengukuran data dicatat dalam tabel pengukuran yang telah disiapkan (Susanto et al. 2017).

Tabel 1. Perbandingan lampu MH dan LED pada penentuan chip LED dalam perancangan lampu LED cumi-cumi

\begin{tabular}{cccccc}
\hline Jenis & Jumlah & Daya & Iluminasi & \multicolumn{2}{c}{ Jumlah chip LED (watt) } \\
\cline { 5 - 7 } lampu & lampu & (watt) & cahaya (lux) & $\mathbf{1 0 0}$ & $\mathbf{5 0}$ \\
\hline MH & 1 & 1500 & 589 & - & - \\
LED & 1 & 100 & 129 & 27 & 54 \\
\hline
\end{tabular}

Tabel 2. Pengukuran data intensitas cahaya lampu MH pada medium udara

\begin{tabular}{ll}
\hline Sudut $\left({ }^{\circ}\right)$ & Intensitas cahaya $\left(\right.$ watt $\left./ \mathbf{c m}^{2}\right)$ \\
\hline 0 & $\ldots$ \\
$\ldots$ & $\ldots$ \\
180 & $\ldots$ \\
\hline
\end{tabular}




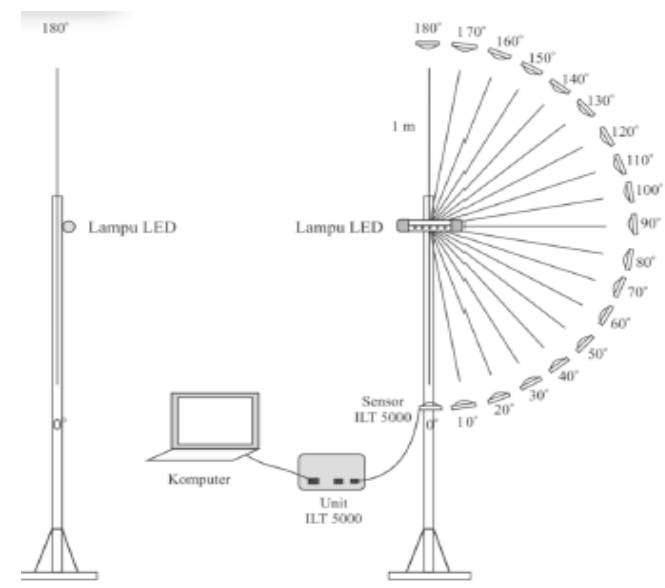

Gambar 1. Pengukuran intensitas cahaya lampu MH pada medium udara

\section{Merancang rangkaian lampu LED cumi- cumi}

Salah satu faktor keberhasilan dari sistem rancangan lampu LED cumi-cumi yaitu ketepatan dalam perhitungan nilai iluminasi agar mampu menyamai iluminasi cahaya yang dihasilkan lampu $\mathrm{MH}$ pada saat pengoperasian. Pemilihan bentuk lampu juga disesuaikan dengan kondisi sifat dari lampu MH yang dioperasikan pada kapal cumi-cumi. Sehingga diperlukan identifikasi bahan-bahan dan peralatan yang dibutuhkan dalam pembuatan lampu ini.

\section{Rancangan bangun rangkaian LED cumi- cumi}

Perancangan LED cumi-cumi yang telah dibuat dengan panjang penampang utama $250 \mathrm{~mm}$ menghasilkan sebaran cahaya yang hampir mirip dengan lampu $\mathrm{MH}$
(Gambar 2 dan 3). Ukuran penampang yang berbentuk segitiga yang dimasukkan ke dalam tabung akrilik dengan panjang $30 \mathrm{~cm}$, diameter $3(72 \mathrm{~mm})$ inci dan ketebalan pipa $4 \mathrm{~mm}$ yang dapat memberikan keefektifan terhadap sebaran cahaya LED yang jangkauannya lebih luas dan memendarkan cahaya seperti lampu MH. Artinya, lampu LED yang dibuat dapat menarik cumi-cumi dengan jangkaun yang jauh dan cumi-cumi dapat berkumpul di sekitar kapal cumicumi.

Faktor keberhasilan dari sistem rancangan lampu LED cumi-cumi yaitu ketepatan dalam perhitungan nilai iluminasi agar mampu menyamakan iluminasi cahaya yang dihasilkan lampu $\mathrm{MH}$ pada saat pengoperasian. Pemilihan bentuk lampujuga disesuaikan dengan kondisi sifat dari lampu MH yang dioperasikan pada kapal cumicumi. Berdasarkan hal tersebut, dilakukan identifikasi bahan-bahan dan peralatan yang dibutuhkan dalam pembuatan LED.

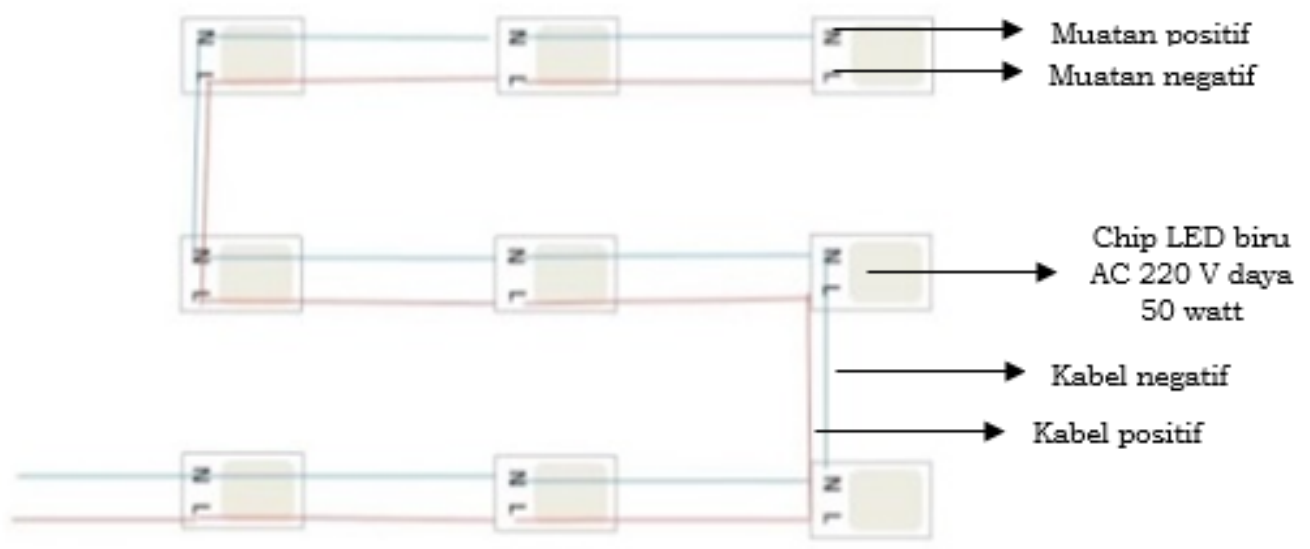

Gambar 2. Skema rangkaian LED cumi-cumi 


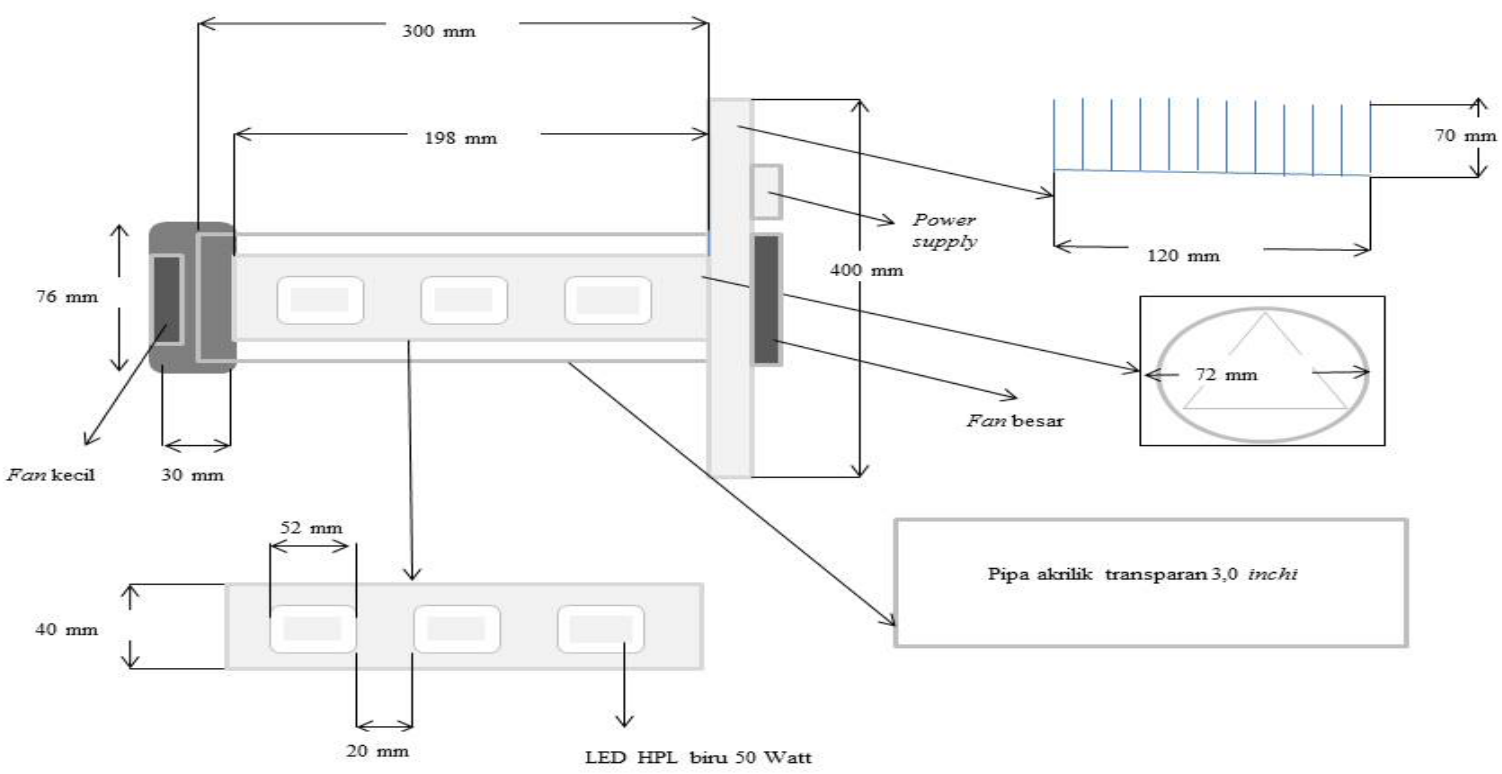

Gambar 3. Rancangan LED cumi-cumi

\section{HASIL DAN PEMBAHASAN}

\section{Rancangan elektronik lampu LED cumi- cumi}

Rangkaian elektronik yang menjadi pertimbangan adalah bagian material dan komponen dari rancang bangun LED 450 watt. Hal ini dilakukan agar lampu yang telah dibuat dapat bertahan lama dan berfungsi dengan baik. Upaya untuk menghindari kerusakan pada saat pengoperasian dengan memasangkan heatsink agar panas yang ditimbulkan tiap chip LED dapat terserap. Heatsink yang digunakan merupakan penyerap panas berbahan alumunium yang cepat dalam menghantarkan panas. Heatsink yang berbahan alumunium dapat menyerap panas dengan baik dengan performa intensitas suhu dan intensitas yang stabil (Sumantri et al. 2017). Karena penggunaan heatsink alumunium memiliki fungsi sebagai peredam panas. Untuk memaksimalkan peredaman panas dipilih heatsink yang memiliki sirip dan desain yang terbuka sebagai aliran udara. Penggunaan material alumunium sebagai heatsink juga dinilai lebih tahan terhadap korosif dibandingkan dengan besi (Ziliwu et al. 2019).

Tahap pertama dari rancang bangun LED cumi-cumi yaitu memilih chip LED berjenis High Power LED 50 watt (Gambar 4) yang telah dipasangkan dengan beberapa komponen pengubah arus Direct Current (DC) ke arus Alternating Current (AC) sehingga dapat langsung disambungkan dengan listrik berdaya 220 volt. Chip LED harganya terjangkau, mudah dikondisikan, daya tahan tinggi bisa bertahan hingga seratus ribu jam. Chip LED yang dipakai cepat panas, sehingga diperlukan heatsink yang tebal dan luas agar dapat cepat menyerap panas dan memiliki suhu yang stabil agar bertahan lama. Dalam proses penyalaan lampu terjadi konveksi udara panas yang mengalir secara alami. Heatsink yang digunakan bertipe trapesium yang dapat menyerap panas secara optimum karena memiliki luas permukaan yang besar (Anggraini 2020).

Rancang bangun pada tahap kedua yaitu menentukan rangkaian listrik yang digunakan pada rangkaian LED sehingga terbentuk rangkaian kontruksi LED cumicumi secara lengkap (Gambar 5). Chip LED dirangkai secara paralel pada daya listrik 220 volt. Sistem rangkaian paralel ini memiliki kelebihan yaitu apabila beban pada satu chip mengalami kerusakan maka tidak mempengaruhi setiap chip LED dalam rangkaian (Taufiq dan Thahir 2019). Total daya keseluruhan yang digunakan dalam rangkaian lampu sebesar 450 watt. Dimana daya tiap chip 50 watt dengan tegangan 220 volt dan arus sebesar 0,227 A. Diagram alir rancang bangun elektronik LED cumi-cumi terdapat pada Gambar 6. 


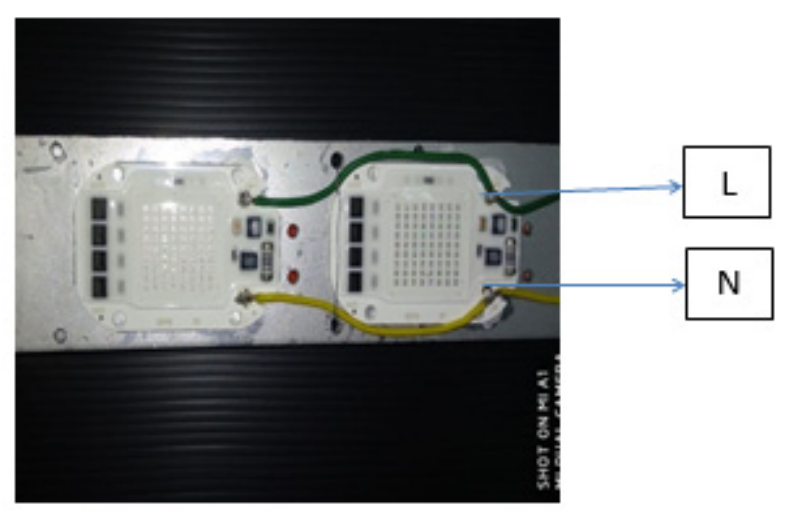

Gambar 4. Chip LED berjenis High Power LED 50 watt

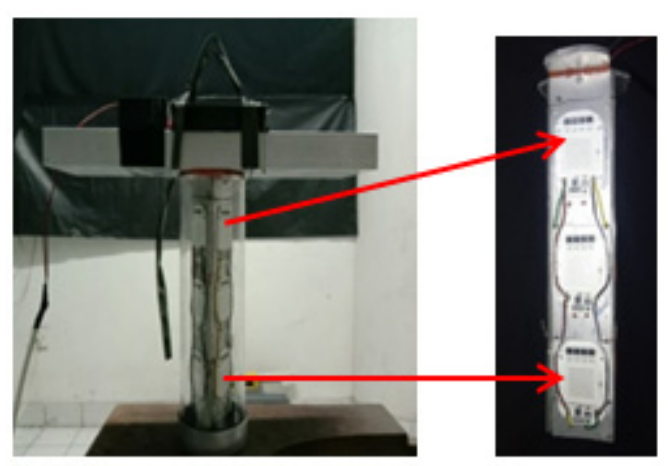

Gambar 5. Rancangan bentuk kontruksi LED cumi-cumi

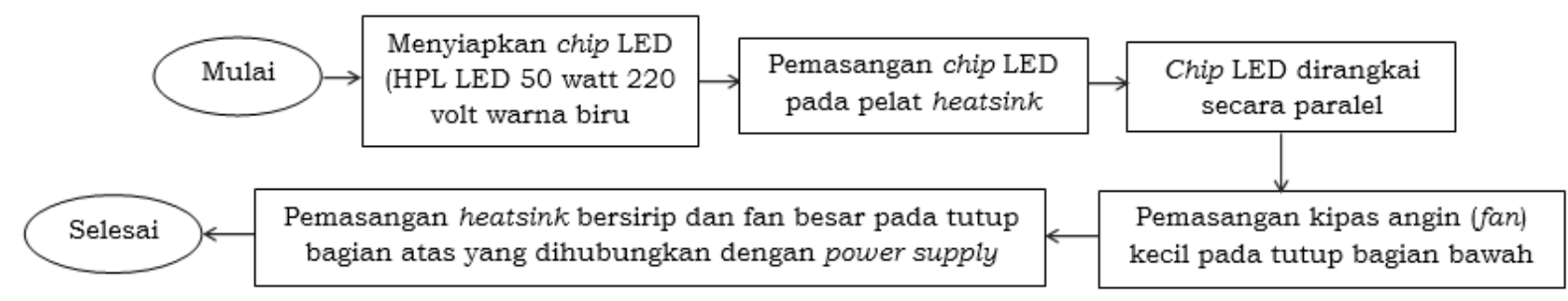

Gambar 6. Diagram alir rancang bangun elektronik LED cumi-cumi

\section{Merancang bentuk kontruksi LED cumi- cumi}

Tahapan yang perlu diperhatikan dalam merancang bentuk kontruksi LED adalah merancang dan membentuk LED agar mendekati bentuk bulat lonjong seperti lampu MH. Kontruksi wadah pemasangan lampu menggunakan heatsink berbentuk pelat persegi panjang yang berguna untuk menyerap panas. Posisi chip LED dalam tabung akrilik dipasang pada pelat heatsink yang membentuk segitiga sama sisi agar dapat masuk dalam tabung pipa akrilik. Heatsink yang dibuat harus disesuaikan dengan casing pipa akrilik yang berukuran panjang 19,8 cm dan diameter 4 inci.
Kemudian ditambahkan sebuah heatsink dengan ukuran $40 \times 12 \times 3,4(\mathrm{~cm})$ pada bagian luar pipa akrilik agar panas yang dihasilkan LED dapat dilepaskan melalui sirip-sirip heatsink. LED juga dipasang fan kecil pada bagian dalam tabung agar dapat mengeluarkan panas pada heatsink tempat LED. Bagian luar juga dipasang fan besar gunanya untuk melepaskan kalor yang terkonduksi dari heatsink pada bagian dalam dan luar tabung. Rancangan bentuk konstruksi LED cumi-cumi disajikan pada Gambar 5.

Chip LED yang dipasang harus dipastikan suhu dan intensitas radiasinya agar dapat dilihat ketahanan dari tiap chip LED (Gambar 7 dan Gambar 8). Kestabilan 
suhu dan intensitas cahaya mempengaruhi daya tahan LED cumi-cumi di dalam rangkaian (Gambar 9). Berdasarkan hasil pengukuran menggambarkan rerata suhu dan intensitas yang dihasilkan dari seluruh chip dalam satu pelat heatsink sebesar $76,11{ }^{\circ} \mathrm{C}$ dan intensitas radiasi cahaya sebesar 1,92E-03 watt $/ \mathrm{cm}^{2}$. Kestabilan suhu pada pengukuran seluruh jumlah chip LED kisaran $27,67-78,83{ }^{\circ} \mathrm{C}$, sedangkan kestabilan intensitas radiasinya berkisar 1,83E-03 - 2,15-03 watt $/ \mathrm{cm}^{2}$ (Gambar 9). Data tersebut menunjukkan bahwa chip LED yang digunakan memiliki suhu yang stabil sehingga kemampuan daya tahan hidup LED relatif cukup lama dan tidak menimbulkan panas pada lingkungan sekitar. Kestabilan suhu pada chip LED akan mempengaruhi juga terhadap kestabilan dari intensitas radiasi cahaya. Suhu panas sering dihasilkan dari akumulasi suhu chip LED menjadi lebih stabil dan dapat diserap panasnya dengan menggunakan heat dissipation berupa heatsink (Lu et al. 2011).

Gambar 10 menjelaskan tentang tingkat kestabilan suhu antara LED dan MH. Dilihat dari grafik rerata suhu lampu LED dan MH masing-masing sebesar 70,16 ${ }^{\circ} \mathrm{C}$ dan 246,11 ${ }^{\circ} \mathrm{C}$. Suhu tertinggi dari lampu LED cumi-cumi hanya sebesar 74,8 ${ }^{\circ} \mathrm{C}$ jauh lebih kecil dibandingkan dengan suhu lampu MH sebesar $265,2{ }^{\circ} \mathrm{C}$. LED dapat berumur panjang apabila suhu yang terukur kurang dari $85{ }^{\circ} \mathrm{C}$ (Handari et al. 2020). Pada Gambar 10 menunjukkan grafik suhu yang didapatkan kurang dari $85^{\circ} \mathrm{C}$, sehingga LED cumi-cumi ketika diuji akan menyala normal dan dapat berumur panjang. Jika dilihat dari Gambar 10 selisih suhu yang sangat jauh antara LED cumicumi dan lampu $\mathrm{MH}$ sebesar $175,95{ }^{\circ} \mathrm{C}$ atau dengan persentase sebesar 247,63\%. Artinya, LED cumi-cumi memiliki tingkat keragaan yang jauh lebih baik dibandingkan dengan lampu MH. Perbedaan suhu yang sangat berbeda jauh dikarenakan komponen dari masing-masing yang berbeda. LED cumi-cumi komponennya merupakan lampu semi konduktor yang menyala apabila diberikan panas. Namun, apabila LED terlalu panas, umur lampu menjadi lebih pendek. Berdasarkan hal tersebut, diperlukan heatsink untuk menempelkan LED, berfungsi untuk menyerap panas secara konduksi dan konveksi. Chip LED dan lampu $\mathrm{MH}$ akan menghasilkan cahaya apabila dialiri arus listrik tapi proses penyalaan dengan tingkatan suhu yang berbeda (Saputro et al. 2013: Hua dan Xing 2013). Untuk memaksimalkan fungsi pendinginan ditambahkan kipas, sehingga suhu chip LED tidak melebihi suhu batas dan stabil (Gambar 9).

Perbandingan intensitas cahaya ini diukur dengan menggunakan International Light Technologies (ILT) 5000 Radiometer Research. Pengukurannya dilakukan pada posisi vertikal yang diambil dari sudut $0^{\circ}$ $180^{\circ}$ dan untuk sudut $180^{\circ}-360^{\circ}$ dianggap nilainya sama pada posisi horizontal. Hal ini dilakukan untuk mengetahui nilai intensitas pada medium udara sehingga dapat terlihat tingkat perbedaan antara LED cumicumi dan lampu MH. Berdasarkan hasil pengukuran intensitas cahaya lampu LED cumi-cumi yang dibuat sudah mendekati lampu MH yang digunakan pada kapal cumi. Lampu MH memiliki grafik berbentuk elips dan sedikit berbeda dengan LED cumi-cumi. Hal ini dipengaruhi karena desain lampu dari LED pada bagian bawah dan atasnya memiliki tutup yang tidak transparan. Rerata intensitas cahaya LED cumi-cumi hanya berkurang 10,57\% dari lampu $\mathrm{MH}$. Walaupun nilainya lebih kecil namun secara perhitungan kebutuhan daya LED masih hemat daya 3 kali lipat dibandingkan dengan lampu MH. Berdasarkan analisis rancang bangun dan teknis secara umum LED hasil rancangan ini dapat digunakan pada kapal cumi-cumi. Namun demikian masih diperlukan penelitian lebih lanjut untuk menguji efektivitas dan efisiensinya dengan melakukan uji coba penangkapan menggunakan kapal LED hasil penelitian pada skala lapangan. Pengurangan pemakaian lampu $\mathrm{MH}$ dan menggantinya dengan lampu LED yang memiliki daya lebih kecil akan menghasilkan nilai intensitas yang sama (Wibisono dan Baheramsyah 2016). Perbandingan sebaran intensitas cahaya LED cumi-cumi dan MH pada medium udara dapat dilihat pada Gambar 11 . 


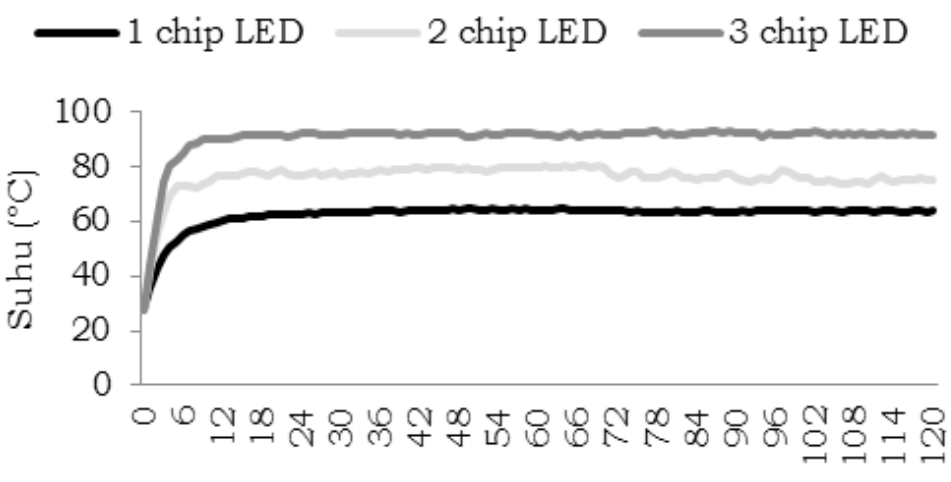

Waktu (menit)

Gambar 7. Grafik perbedaan nilai suhu tiap jumlah chip LED

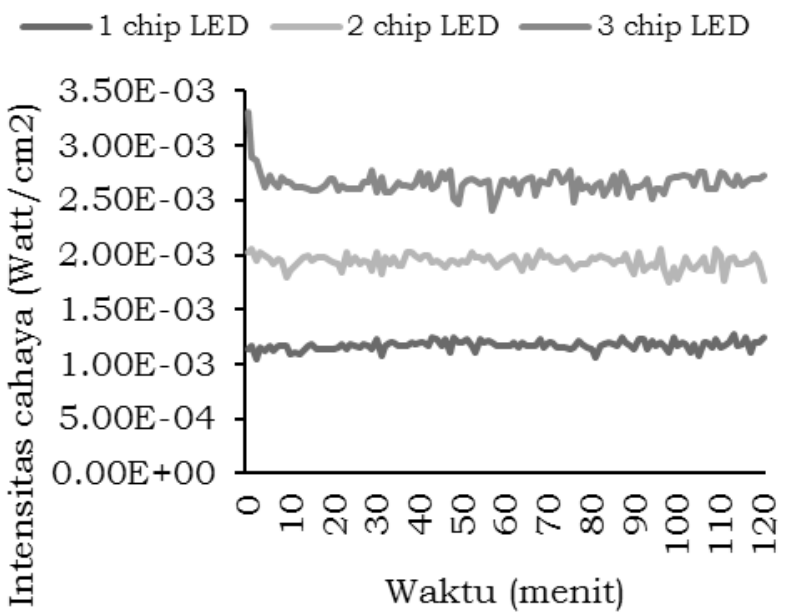

Gambar 8. Grafik perbedan nilai intensitas cahaya tiap jumlah chip LED

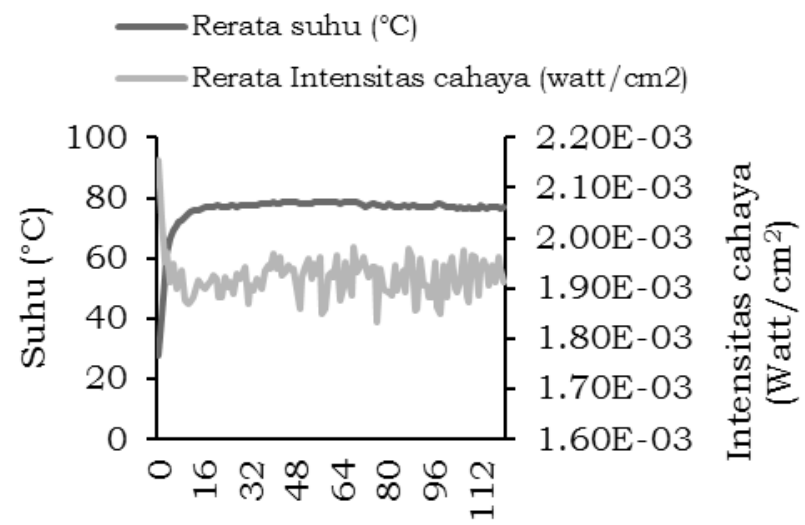

Waktu (menit)

Gambar 9. Grafik rerata suhu dan intensitas cahaya chip LED 


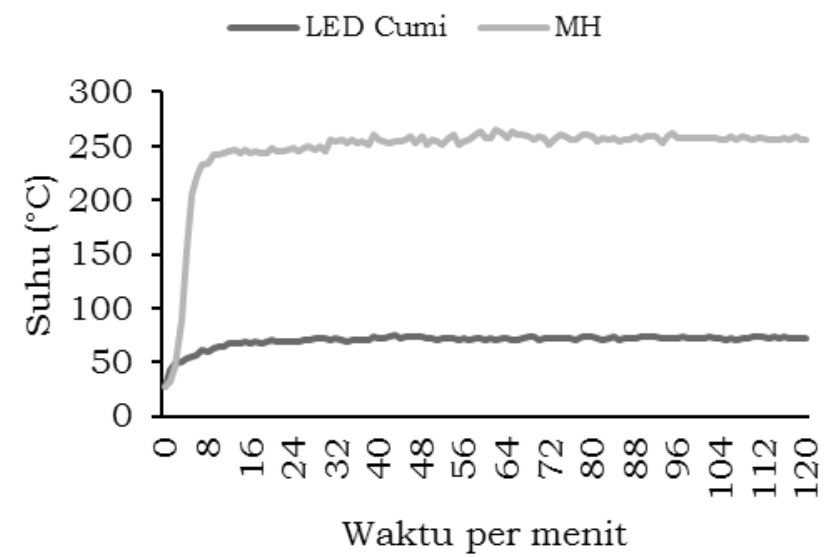

Gambar 10. Grafik rerata suhu LED cumi-cumi dan lampu MH

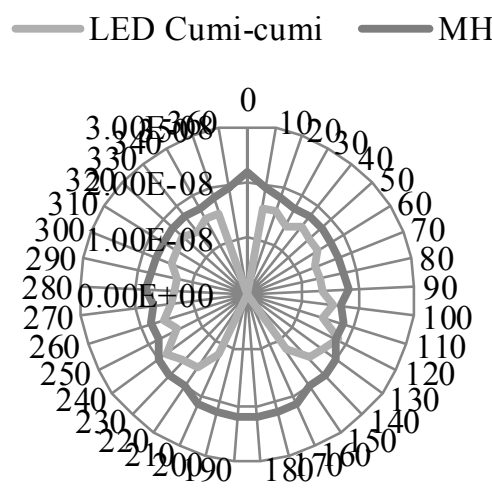

Gambar 11. Grafik perbandingan intensitas cahaya LED cumi-cumi dan lampu MH pada medium udara

\section{KESIMPULAN DAN SARAN}

\section{Kesimpulan}

Rancang bangun LED cumi-cumi yang telah dibuat mulai dari merancang bangun elektronik dan membentuk kontruksi lampu telah mendekati hipotesis penelitian. Tiap chip LED memiliki nilai suhu dan tingkat iluminasi yang stabil mulai dari menit ke-12 hingga sampai akhir pengamatan. Intensitas cahaya yang dihasilkan LED cumi-cumi juga berhasil mendekati intensitas cahaya lampu $\mathrm{MH}$. Sebaran cahaya lampu LED cumi-cumi hanya berkurang $10,57 \%$. Artinya, lampu LED cumi-cumi cukup efektif terhadap sebaran cahaya yang dihasilkan dengan daya yang lebih rendah dibandingkan dengan lampu $\mathrm{MH}$.

\section{Saran}

Rancang bangun lampu perlu
menggunakan heatsink yang mampu

menyerap panas lebih besar sehingga desain lampu LED cumi-cumi lebih kompatibel. Desain lampu LED cumi-cumi bagian tutup atas dan bawah harus berbahan yang bersifat transparan karena pada sudut $0^{\circ}$, $160^{\circ}, 170^{\circ}$, dan $180^{\circ}$ memiliki intensitas cahaya bernilai 0 watt $/ \mathrm{cm}^{2}$.

\section{DAFTAR PUSTAKA}

Anggraini R, Sudarma AF, Yuliarty P, Eurika FV. 2020. Perancangan Heatsink untuk Lampu LED Menggunakan Simulasi CFD. Jurnal Teknik Indsutri ITN Malang. 10(1): 6-10.

Christianto K. 2019. Dampak Peralihan Armada Penangkapan Cast Nets ke Squid Jigging dari Aspek Teknologi Ekonomi dan Sosial [Skripsi]. Bogor (ID): Institut Pertanian Bogor.

Handari YW, Soeprapto, Hasanah RN. 2020. Rancang Bangun Lampu Bohlam DC Menggunakan LED untuk Sistem Rumah DC. Jurnal Mahasiswa 
Teknik Elektro Uiversitas Brawijaya. 2(2): 1-6.

Hua LT, Xing J. 2013. Research on LED Fishing Light. Research Journal of Applied Sciences Engineering and Technology. 5(16): 4138-4141.

Kuo CY, Shen SC. 2018. Design of Secondary Lens for LED Fishing Lamps to Evaluation Catches Energy Efficiency in Saury Fishing. IEEE Access. 6(1): 66664-66673.

Lu X, Hua TC, Wang YP. 2011. Thermal Analysis of High Power LED Package ith Heat Pipe Heat Sink. Microelectronics Journal. 42: 1257 1262.

Matsushita Y, Azuno T, Yamashita Y. 2012. Fuel Reduction in Coastal Squid Jigging Boats Equipped with Various Combinations of Conventional Metal Halide Lamps dan Low-Energy LED Panels. Fisheries Research. 125-125: 14-19.

Rudin MJ, Irnawati R, Rahmawati A. 2017. Perbedaan Hasil Tangkapan Bagan Tancap dengan Menggunakan Lampu CFL dan LED dalam Air (Leda) di Perairan Teluk Banten. Jurnal Perikanan Kelautan. 7(2): 167-180.

Saputro JH, Sukmadi T, Karnoto. 2013. Analisa Penggunaan Lampu LED pada Penerangan dalam Rumah. Transmisi. 15(1): 19-27.

Shen SC, Kuo CY, Fang MC. 2013. Design and Analysis of an Underwater White LED Fish-Attracting Lamp and Its Light Propagation. International Journal of Advanced Robotic Systems. 10(3): 1-10.

Sofijanto MA, Arfiati D, Lelono TD, Muntaha A. 2018. Efficiency Comparrison of LED and $\mathrm{MH}$ Lamps in Purse
Seine Fisheries. Turkish Journal of Fisheries and Aquatic Sciences. 19(1): 131-139.

Sumantri Y, Pramono GE, Nurrohman. 2017. Studi Eksperimental Pendingin Pasif Lampu Light Emitting Diode untuk Aplikasi Fotografi. Jurnal Ilmiah Teknik Mesin. 3(1): 7-12.

Susanto A, Irnawati R, Mustahal, Syabana MA. 2017. Fishing Efficiency of LED Lamps for Fixed Lift Net Fisheries in Banten Bay Indonesia. Turkish Journal of Fisheries and Aquatic Sciences. 17(1): 283-291.

Taufiq, Thahir MA. 2019. Pembuatan Lampu LED Celup untuk Perikanan Bubu di Perairan Lhok Bubon Kabupaten Aceh Barat. Jurnal Perikanan Tropis. 6(1): 13-24.

Tirtana D. 2019. Respons dan Tingkah Laku Cumi-Cumi (Uroteuthis Duvaucelli, D'orbigny 1835) terhadap Cahaya Lampu Light Emitting Diode [Tesis]. Bogor (ID): Institut Pertanian Bogor.

Wibisono SR, Baheramsyah A. 2016. Analisa Teknis Pemakaian Kombinasi Lampu Metal Halide dan LED sebagai Pengikat Ikan pada Kapal Pukat Cincin (Purse Seine) dan Pengaruhnya terhadap Komposisi Bahan Bakar Genset. Jurnal Sains dan Seni ITS. 5(2): G371-G375.

Yamashita Y, Matsushita Y, Azuno T. 2012. Catch Performance of Coastal Squid Jigging Boats Using LED Panels in Combination with Metal Halide Lamps. Fisheries Research. 113(1): 182-189.

Ziliwu BW, Yaqin RI, Arkham MN, Daulay HA. 2019. Perancangan Lampu Light Emitting Diode (LED) Pemikat Ikan. Aurelia Jurnal. 1(1): 12-17. 